\title{
Cholestasis and hypercalcemia secondary to panhypopituitarism in a newborn
}

\author{
Fatma Dursun ${ }^{1}$, Nelgin Gerenli², Heves Kırmızıbekmez ${ }^{1}$ \\ Departments of ${ }^{1}$ Pediatric Endocrinology and ${ }^{2}$ Pediatric Gastroenterology, Ümraniye Training and Research Hospital, \\ Istanbul, Turkey. E-mail: fatmadursun54@yahoo.com \\ Received: 16th May 2016, Revised: 26th December 2016, Accepted: 18th January 2017
}

SUMMARY: Dursun F, Gerenli N, Kirmizibekmez H. Cholestasis and hypercalcemia secondary to panhypopituitarism in a newborn. Turk J Pediatr 2017; 59: 100-103.

Cholestatic hepatitis and hypercalcemia are rare features of hypopituitarism in newborns. So diagnosis of hypopituitarism is frequently delayed. The most frequent symptoms of congenital hypopituitarism are hypoglycemia, prolonged jaundince and micropenis. A patient with congenital hypopituitarism associated with cholestasis and hypercalcemia is reported here. Newborns with hypercalcemia and cholestasis should alert pediatricians to the possibility of congenital hypopituitarism and prompt endocrinological investigation.

Key words: newborn, cholestatic hepatitis, hypercalcemia, hypopituitarism.

The rare disorder of hypopituitarism of infancy is clinically characterized by failure to thrive, recurrent hypoglycemia, and prolonged jaundice caused by cholestatic hepatitis. The endocrinological diagnosis is frequently delayed and the majority of infants with hypopituitarism and neonatal cholestasis undergo liver biopsy ${ }^{1-3}$.

Congenital hypopituitarism is diagnosed by either partial or complete deficiency of pituitary hormone secretion. Thyroid stimulating hormone (TSH) deficiency is indicated by low basal serum free/total thyroxin (fT4/ T4) with an inappropriately normal or low $\mathrm{TSH}$. Adrenocorticotropin hormone (ACTH) deficiency is indirectly diagnosed based on a decreased basal ( $8 \mathrm{am}$ ) cortisol level in untreated infants. Growth hormone $(\mathrm{GH})$ deficiency is defined as a low GH level or low insulin-like growth factor- 1 (IGF- 1) and /or insulin-like binding protein- 3 (IGFBP3). Gonadotropin deficiency is identified by low follicle-stimulating hormone (FSH) and luteinizing hormone ( $\mathrm{LH}$ ) levels for a given age ${ }^{4}$.

Congenital hypopituitarism is an uncommon cause of neonatal cholestasis. It is unclear which hormone causes cholestasis in patients with congenital panhypopituitarism. Some authors suggested that growth hormone deficiency is the major cause of cholestasis ${ }^{5-7}$. But there is now good evidence that central adrenal insufficiency is the main cause of cholestatic hepatitis in hypopituitarism. Glucocorticoids were shown to augment bile flow in vitro as well as in rats and dogs $3,8-10$.

Hypercalcemia was reported in $5.5 \%$ of primary adrenocortical insufficiency in adults. The proportion of hypercalcemia is unknown in secondary adrenocortical insufficiency. Although the mechanism of hypercalcemia in adrenocortical insufficiency is unknown, lack of serum cortisol is considered to be related with increased calcium reabsorbtion from renal tubules and release from bone 11,12.

We report a male newborn with panhypopituitarism who presented with hypercalcemia, hypoglycemia and cholestasis.

\section{Case Report}

A male infant with a birth weight of 3900 $\mathrm{g}$ born via caesarean section at full term to non-consanguineous parents was referred to our newborn intensive care unit from an outside center for further work-up of hypoglycemia and newborn convulsion 12 hours after birth. On physical examination, his body weight was $3740 \mathrm{~g}$. His general status was poor. He was intubated due to 
respiratory stress. His anterior fontanel was $2 \times 1.5 \mathrm{~cm}$. There was no cardiac murmur, hepatosplenomegaly, abdominal distension, or dysmorphic features. Testes were bilaterally in scrotum, and extended penis length was $2 \mathrm{~cm}$. Considering congenital pneumonia, cultures were obtained and antibiotic treatment was begun. He was extubated 2 days later. Antibiotics were stopped 7 days later since no growth occurred in the cultures. Hypoglycemia did not recur. An EEG and metabolic screens for convulsions were all normal. His jaundice was intensified on the third day after birth and therefore he was put on phototherapy. As bilirubin level continued to rise despite phototherapy, phenobarbital was administered for 3 days. Cholestasis and hypercalcemia started at $7^{\text {th }}$ and $15^{\text {th }}$ day, respectively (Table I). The patient was referred to the pediatric endocrinology division at 15th day for evaluating the etiology of cholestasis, hypercalcemia and hyperphosphatemia. TORCH, hepatitis serology, $\alpha-1$ antitrypsin, and fecal elastase studies for the differential diagnosis of cholestasis were all normal. Cortisol deficiency was considered due to cholestasis and hypercalcemia. Low dose ACTH test was performed with $1 \mu \mathrm{g} \mathrm{ACTH.}$ Since he had cortisol levels of less than $1 \mathrm{mg}$ / $\mathrm{dl}$ at $0^{\text {th }}$ and $30^{\text {th }}$ minutes, the patient was evaluated for panhypopituitarism (Table I). Thyroid function test was normal at $7^{\text {th }}$ day but central hypothyroidism was detected at $18^{\text {th }}$ day (Table I). In addition to an extended penis length of $2 \mathrm{~cm}$, patient's hypogonadotropic hypogonadism was also confirmed by laboratory examinations (Table I). A hypophysis MRI revealed a hypophyseal height of $1.5 \mathrm{~mm}$ and an ectopic neurohypophysis. Based on these findings a diagnosis of panhypopituitarism was made. The patient was put on hydrocortisone $\left(10 \mathrm{mg} / \mathrm{m}^{2}\right.$ day) and L-thyroxine $(8 \mu \mathrm{g} / \mathrm{kg}$ day). The patient could tolerate oral feeding after hydrocortisone therapy. Hypercalcemia also improved. The patient's cholestasis recovered at $45^{\text {th }}$ day. Now 20-month-old, he does not take growth hormone yet since his height and growth rate remained normal. PROP- 1 mutation analysis for the genetic etiology of panhypopituitarism was normal. This case was reported to stress that newborns with cholestasis and hypercalcemia should definitely be investigated for cortisol deficiency and panhypopituitarism.

\section{Discussion}

Congenital panhypopituitarism is a rare disease, of variable clinic. The neonatal hypoglycemia is one of the habitual forms of presentation, the cholestasis is a rare symptom of this disease. The incidence of neonatal cholestasis associated with neonatalhypopituitarism is unknown.

Which hormone deficiency causes cholestasis is unclear. It has been shown that some hormonal disorders can alter liver function, particularly at the neonatal period. The pattern of liver dysfunction secondary to hormone deficiencies such as growth hormone deficiency, hypocortisolism, or hypothyroidism is variable and goes from predominantly direct hyperbilirubinemia with cholestasis, or cholestasis with elevated hepatic enzymes ${ }^{4,13}$. Some authors suggested that growth hormone deficiency was the major factor yielding cholestasis $^{6}$. Drop et al. ${ }^{14}$ supported this hypothesis by observing that cholestasis did not resolve with thyroxin and hydrocortisone therapies in two infants with hypopituitarism. But another study showed that cholestasis was unresponsive to thyroxin but resolved with hydrocortisone therapy ${ }^{15}$. Gönç et al. ${ }^{16}$ showed that primary and central adrenal insufficiency can cause cholestatic hepatititis. Similarly, a study by Al-Hussaini et al. ${ }^{6}$ showed that cholestasis recovered after hydrocortisone therapy in 4 cases, of which two had primary and two had secondary adrenal failure. Cholestasis of our patient also recovered by 45 days with hydrocortisone and L-thyroxine therapy. As the patient did not have hypoglycemia and his height percentile and growth rate were still normal, growth hormone was not begun.

Hypercalcemia is a very rare finding of adrenal failure, and there are too few studies published on this subject ${ }^{11,12}$. The postulated mechanism of adrenal insufficiency causing hypercalcaemia is through a combination of increased calcium renal excretion. Decreased glomerular filtration results in a reduced filtered load of calcium, and increased calcium renal reabsorbtion occurs due to volume depletion in adrenal insufficiency. Enhanced calcium mobilization from bone by hypoadrenalism also contributes to the development of hypercalcaemia ${ }^{12,17}$.

Patient history and a careful physical examination provide additional tools to unearth the underlying etiology of prolonged neonatal 
Table I. Laboratory Findings of the Patient

\begin{tabular}{|c|c|c|c|c|c|c|}
\hline $\begin{array}{l}\text { Laboratory } \\
\text { findings }\end{array}$ & $1^{\text {st }}$ day & $7^{\text {th }}$ day & $15^{\text {th }}$ day & $18^{\text {th }}$ day & $33^{\text {th }}$ day & $4^{\text {th }}$ day \\
\hline $\begin{array}{l}\text { CRP } \\
(\mathrm{mg} / \mathrm{dl})(\mathrm{N}<0 .\end{array}$ & 0.2 & 0.2 & 0.2 & & 0.2 & \\
\hline $\begin{array}{l}\text { 6) } \\
\text { ÁLT(IU/L) }\end{array}$ & 15 & 81 & 22 & 15 & 68 & 24 \\
\hline AST (IU/L) & 61 & 43 & 41 & 42 & 102 & 36 \\
\hline GGT (IU/L) & NA & 603 & 213 & 154 & 94 & 43 \\
\hline ALP(IU/L) & & 110 & 144 & 218 & 588 & 123 \\
\hline $\begin{array}{l}\text { Total } \\
\text { bilirubin }\end{array}$ & 6.3 & 17.2 & 10.7 & 7.8 & 7.7 & 0.6 \\
\hline $\begin{array}{l}\text { (mg/dl) } \\
\text { Direct } \\
\text { bilirubin }\end{array}$ & 1.07 & 1.53 & 3.03 & 3.8 & 5.7 & 0.5 \\
\hline $\begin{array}{l}\text { (mg/dl) } \\
\text { Glucose } \\
\text { (mg/dl) }\end{array}$ & 80 & 70 & 72 & 73 & 67 & 80 \\
\hline $\begin{array}{l}\text { Sodium } \\
\text { (mEq/L) }\end{array}$ & 137 & & 139 & & & 140 \\
\hline $\begin{array}{l}\text { Potassium } \\
(\mathrm{mEq} / \mathrm{L})\end{array}$ & 4.5 & & 4.6 & & & 4 \\
\hline $\begin{array}{l}\text { Calcium } \\
\text { (mg/dl) }\end{array}$ & 9.8 & 10.6 & 12.4 & 9.1 & 10.3 & 10 \\
\hline $\begin{array}{l}\text { Phosphorus } \\
\text { (mg/dl) }\end{array}$ & 5.1 & 7.8 & 7.9 & 4.9 & 5.8 & 5.8 \\
\hline $\begin{array}{l}\mathrm{TSH} \\
(\mathrm{mIU} / \mathrm{ml})\end{array}$ & & 2.2 & & 6.9 & 2.8 & 0.05 \\
\hline $\begin{array}{l}\text { Free-T4 } \\
\text { (ng/dl) }\end{array}$ & & 0.95 & & 0.61 & 0.85 & 1.2 \\
\hline $\begin{array}{l}\text { (N:0,8-2.4) } \\
\text { Baseline } \\
\text { cortisole ( }(\mu \mathrm{g} / \mathrm{dl})\end{array}$ & & & & $<1$ & & \\
\hline $\begin{array}{l}30^{\text {th }} \text { minute } \\
\text { cortisole }\end{array}$ & & & & $<1$ & & \\
\hline $\begin{array}{l}(\mu \mathrm{g} / \mathrm{dl})(\mathrm{N}>18) \\
\text { ACTH }(\mathrm{pg} / \mathrm{ml}) \\
(\mathrm{N}<60)\end{array}$ & & & & 13.7 & & \\
\hline $\begin{array}{l}\text { PTH(pg/ml) } \\
(\mathrm{N}: 15-60)\end{array}$ & & & & 15.6 & & \\
\hline $\begin{array}{l}25 \mathrm{OHD} 3 \\
(\mathrm{ng} / \mathrm{ml})\end{array}$ & & & & 27.7 & & \\
\hline $\begin{array}{l}(\mathrm{N}>20) \\
\text { IGF- } 1 \\
(\mathrm{ng} / \mathrm{ml}) \\
(\mathrm{N}: 25-200))\end{array}$ & & & & & $<25$ & \\
\hline $\begin{array}{l}\mathrm{LH}(\mathrm{mIU} / \mathrm{ml}) \\
(\mathrm{N}: 0.05-7)\end{array}$ & & & & & $<0.05$ & \\
\hline $\begin{array}{l}\text { FSH }(\mathrm{mIU} / \mathrm{ml}) \\
(\mathrm{N}: 0.16-4.1)\end{array}$ & & & & & $<0.05$ & \\
\hline $\begin{array}{l}\text { Total } \\
\text { Testosterone }\end{array}$ & & & & & $<0.13$ & \\
\hline $\begin{array}{l}(\mathrm{ng} / \mathrm{ml})(\mathrm{N} \text { : } \\
\text { 0.6-4) } \\
\text { Respiratory } \\
\text { support }\end{array}$ & \multirow{2}{*}{$\begin{array}{l}\text { Intubation } \\
\text { (mechanical } \\
\text { ventilation) } \\
\text { Ampicillin+ } \\
\text { amikacin }\end{array}$} & $\begin{array}{l}\text { Spontaneous } \\
\text { respiration }\end{array}$ & $\begin{array}{l}\text { Spontaneous } \\
\text { respiration }\end{array}$ & $\begin{array}{l}\text { Spontaneous } \\
\text { respiration }\end{array}$ & & \\
\hline Medication & & $\begin{array}{l}\text { Vancomycin }+ \\
\text { meropenem }\end{array}$ & $\begin{array}{l}\text { Vancomycin }+ \\
\text { meropenem }\end{array}$ & $\begin{array}{l}\text { Hydrocortisone } \\
\left(10 \mathrm{mg} / \mathrm{m}^{2} / \text { day }\right. \\
\text { L-thyroxine } \\
(8 \mu \mathrm{g} / \mathrm{kg} / \text { day })\end{array}$ & $\begin{array}{l}\text { Hydrocortisone } \\
\text { (10 mg/m } 2 / \text { day } \\
\text { L-thyroxine } \\
(8 \mu \mathrm{g} / \mathrm{kg} / \text { day })\end{array}$ & $\begin{array}{l}\text { Hydrocortisone } \\
\left(10 \mathrm{mg} / \mathrm{m}^{2} / \text { day }\right. \\
\text { L-thyroxine } \\
(4 \mu \mathrm{g} / \mathrm{kg} / \text { day })\end{array}$ \\
\hline
\end{tabular}

CRP: C-reactive protein, ALT: alanine aminotransferase, AST:aspartate aminotransferase,, GGT: Gama glutamyl transferase, ALP:alkaline phosphatase, TSH: thyroid-stimulating hormone, free-t4: free thyroxine, $\mathrm{N}$ : normal, ACTH: adrenocorticotropine hormone, $25 \mathrm{OH}$ vit D3: 25 hydroxy vitamin D3, PTH: parathyroid hormone, IGF-1: insulin growth factor-1, LH: luteinizing hormone, FSH: follicle stimulating hormone, MRI: Magnetic Resonance Imaging 
cholestatis in infants since most children are oligosymptomatic. Delayed diagnosis of an underlying endocrine disease predisposes these patients to higher morbidity risks due to hypoglycemia, adrenal insufficiency, and hypothyroidism ${ }^{1,13}$.

In conclusion; newborns with hypoglycemia, hypercalcemia and cholestasis should alert pediatricians to the possibility of congenital hypopituitarism and prompt endocrinological investigation.

\section{REFERENCES}

1. Choo-Kang LR, Sun CC, Counts DR. Cholestasis and hypoglycemia: manifestations of congenital anterior hypopituitarism. J Clin Endocrinol Metab 1996; 81: 2786-2789.

2. Spray $\mathrm{CH}$, Mckieman P, Waldron KE, Shaw N, Kirk J, Kelly DA. Investigation and outcome of neonatal hepatitis in infants with hypopituitarism. Acta Pediatr 2000; 89: 951-954

3. Binder G, Martin DD, Kanther I, Schwarze CP, Ranke MB. The course of neonatal cholestasis in congenital combined pituitary hormone deficiency. J Pediatr Endocrinol Metab 2007; 20: 695-701.

4. Karnsakul W, Sawathiparnich P, Nimkarn S, Likitmaskul S, Santiprabhob J, Aanpreung P. Anterior pituitary hormone effects on hepatic functions in infants with congenital hypopituitarism. Ann of Hepatol 2007; 6: 97-103.

5. DeSalvo D, Pohl JF, Wilson DP, et al. Cholestasis secondary to panhypopituitarism in an infant. J Natl Med Assoc 2008; 100: 342-344.

6. Copeland KC, Franks RC, Ramamurthy R. Neonatal hyperbilirubinemia and hypoglycemia in congenital hypopituitarism. Clin Pediatr (Phila) 1981; 20: 523526.
7. Al-Hussaini A, Almutairi a, Mursi a, Alghofely M, Asery A. Isolated cortisol deficiency: a rare cause of neonatal cholestasis. Saudi J Gastroenterol 2012; 18: 339-341.

8. Bauman JW Jr, Chang BS, Hall FR. The effects of adrenalectomy and hypophysectomy on bile flow in the rat. Acta Endocrinol 1966; 52: 404-408.

9. Macarol V, Morris TQ, Baker KJ, Bradley SE. Hydrocortisone choleresis in the dog. J Clin Invest 1970; 49: 1714-1723

10. Fardel O, Payen L, Courtois A, Vernhet L, Lecureur $\mathrm{V}$. Regulation of biliary drug efflux pump expression by hormones and xenobiotics. Toxicology 2001; 167: 37-46.

11. Harano Y, Kitano A, Akiyama Y, Kotajima L, Honda $\mathrm{K}$, Arioka $\mathrm{H}$. A case of isolated adrenocorticotropic hormone deficiency; a rare but possible cause of hypercalcemia. Int Med Case Rep J 2015; 27: 77-79.

12. Lee AS, Twigg SM. Opioid-induced secondary adrenal insufficiency presenting as hypercalcaemia. Endocrinol Diabetes Metab Case Rep 2015; 2015: 150035.

13. Braslavsky D, Keselman A, Galoppo M, et al. Neonatal cholestasis in congenital pituitary hormone deficiency and isolated hypocortisolism: characterization of liver dysfunction and follow-up. Arq Bras Endocrinol Metabol 2011; 55: 622- 627

14. Drop SL, Colle E, Guyda HJ. Hyperbilirubinaemia and idiopathic hypopituitarism in the newborn period. Acta Paediatr Scand 1979; 68: 277-280.

15. Steinherz R, Rachmel A, Josephsberg Z, et al Hydrocortisone resolves persistent neonatal jaunice in multipl pituitary hormone deficiencies. Helv Paediatr Acta 1988; 43: 219-223.

16. Gönç EN, Kandemir N, Andıran N, Özön A, Yordam $\mathrm{N}$. Cholestatic hepatitis as a result of severe cortisol deficiency in early infancy: report of two cases and review of literature. Turk J Pediatr 2006; 48: 376- 379.

17. Muls E, Bouillon R, Boelaert J, et al. Etiology of hypercalcemia in a patient with Addison's disease. Calcif Tissue Int 1982; 34: 523-526. 